\title{
Persepsi Perempuan terhadap Pemanfaatan Pekarangan Mendukung Diversifikasi Pangan di Sulawesi Utara
}

\section{Women's Perception on Home Gardening can Support Food Diversification in North Sulawesi}

\author{
Conny N. Manoppo ${ }^{1}$, Siti Amanah², Pang S. Asngari², Prabowo Tjitropranoto ${ }^{2}$ \\ ${ }^{1}$ Balai Pengkajian Teknologi Pertanian Sulawesi Utara, Makasar \\ ${ }^{2}$ Departemen Sains Komunikasi dan Pengembangan Masyarakat Fakultas Ekologi Manusia, \\ Institut Pertanian Bogor, Bogor
}

\begin{abstract}
The objective of the study was to analyze women's perception about the functions and benefits of home gardening, food diversification and healthy foods. Research locations were in Minahasa and Bitung Regency, North Sulawesi. The study was conducted from March to December 2015 involving 267 respondents, 140 of whom were from Minahasa and 127 from Bitung, who were selected out of 803 women participating in the home gardening intensification programs. Data were analyzed using descriptive analysis, Rank Spearman correlation and Mann Whitney tests. Results showed that the level of women's perception about the functions, benefits of home gardening, food diversification and healthy foods was in high category. There was a different perception about food diversification between the Minahasa and Bitung. Perceptions about functions and benefits of the home gardening were associated with the availability and suitability of the information, the availability of the production inputs, family support and groups' roles. Perceptions about food diversification were positively associated with the number of family members, the suitability of information, credibility of the information contributor, and availability of the production inputs. Perceptions about healthy foods were negatively associated with time allocation and positively associated with the suitability of the information, availability of the production inputs, the group roles, and extension. To build a positive perception of home gardening information such as extension materials that are required by women, group support, and support of production inputs is needed.
\end{abstract}

Keywords: perception and information, home gardening, food diversification

\begin{abstract}
Abstrak
Penelitian bertujuan menganalisis persepsi perempuan tentang fungsi dan manfaat pekarangan, diversifikasi pangan dan makanan sehat. Penelitian dilakukan di Kabupaten Minahasa dan Kota Bitung Provinsi Sulawesi Utara. Penelitian dilakukan mulai Maret hingga Desember 2015, melibatkan 267 responden terdiri dari 140 responden di Minahasa dan 127 responden di Bitung, dipilih dari 803 perempuan peserta program pemanfaatan pekarangan Data dianalisis menggunakan statistik deskriptif, analisisis korelasi Rank Spearman dan uji Mann Whitney. Hasil analisis statistik deskriptif menyatakan, tingkat persepsi responden terhadap fungsi dan manfaat pekarangan, diversifikasi pangan dan makanan sehat berada pada kategori tinggi. Terdapat perbedaan persepsi terhadap diversifikasi pangan antara Minahasa dan Bitung. Persepsi tentang fungsi dan manfaat pekarangan berhubungan dengan: ketersediaan dan kesesuaian informasi, ketersediaan sarana produksi, dukungan keluarga, peran kelompok dan penyuluhan. Persepsi tentang diversifikasi pangan berhubungan nyata dengan jumlah anggota keluarga, kesesuaian informasi, kredibilitas pemberi informasi, dan ketersediaan sarana produksi. Persepsi tentang makanan sehat berhubungan negatif dengan curahan waktu dan berhubungan positif dengan kesesuaian informasi, ketersediaan sarana produksi, peran kelompok, dan penyuluhan. Untuk membangun persepsi positif terhadap pemanfaatan pekarangan diperlukan informasi berupa materi penyuluhan sesuai kebutuhan perempuan, penguatan kelompok, dan dukungan sarana produksi.
\end{abstract}

Kata kunci: persepsi dan informasi, pekarangan, diversifikasi pangan

\section{Pendahuluan}

Ketahanan pangan secara makro tidak menjamin ketahanan pangan di tingkat mikro atau rumah tangga. Salim et al., (Ariningsih dan Handewi, 2008) menunjukkan bahwa, walaupun ketahanan pangan di tingkat provinsi tergolong tahan pangan, namun masih ditemukan rumah tangga yang tergolong rawan pangan dengan proporsi relatif tinggi, sehingga upaya mencapai ketahanan pangan nasional harus dimulai dengan mewujudkan ketahanan pangan di tingkat rumah tangga sebagai bentuk masyarakat terkecil. Maturbongs 
(2008) menyatakan, perlunya penguatan pada sistem pangan nasional dan wilayah agar ketahanan pangan sampai pada tingkat rumah tangga dapat tercapai. Upaya peningkatan ketahanan pangan pada rumah tangga tidak dapat dipisahkan dari aspek diversifikasi (penganekaragaman) pangan.

Tujuan diversifikasi pangan adalah untuk memperluas pilihan masyarakat dalam kegiatan konsumsi pangan, tidak hanya sekedar pemenuhan kebutuhan jumlah pangan yang dikonsumsi, namun juga harus memperhatikan kandungan gizi yang seimbang agar dapat hidup sehat.

Keterbatasan terhadap upaya pemenuhan bahan pangan baik dari ketersediaan pangan dan daya beli, sering menjadi alasan tidak tercukupinya kebutuhan gizi keluarga. Padahal untuk memenuhi kebutuhan pangan yang bergizi, tidak harus selalu dengan membeli, keluarga dapat memanfaatkan lahan pekarangan. Data menunjukkan, luas lahan pekarangan secara nasional sekitar 10,3 juta ha atau 14\% dari keseluruhan luas lahan pertanian. Luas lahan pekarangan tersebut merupakan salah satu sumber potensial bagi penyedia bahan pangan yang bernilai gizi dan memiliki nilai ekonomi tinggi BP2TP (2011).

Hingga saat ini, pengelolaan lahan pekarangan sebagai sumber bahan pangan yang beragam dan sumber gizi yang aman bagi keluarga, belum dikelola secara optimal dan berkelanjutan bahkan cenderung dibiarkan begitu saja. Hal ini antara lain disebabkan kurangnya inovasi teknologi pemanfaatan pekarangan yang sesuai, kurangnya pendampingan dari petugas, serta masih kurangnya kesadaran pemilik pekarangan. Pemilik pekarangan belum terbiasa memanfaatkan lahan pekarangan secara produktif, serta belum menganggap lahan pekarangan sebagai lahan yang potensial untuk dimanfaatkan secara optimal sebagai penyedia, menjaga dan meningkatkan ketahanan pangan rumah tangga. Sikap seperti ini tidak terlepas dari persepsi perempuan (ibu rumah tangga) sebagai pemilik pekarangan. Untuk itu diperlukan upaya optimalisasi pemanfaatan pekarangan dan membentuk persepsi positif dari pemilik pekarangan.

Optimalisasi pekarangan menjadi hal yang penting karena tingginya laju alih fungsi lahan dan adanya ancaman terhadap sistem produksi pangan. Upaya ini merupakan salah satu alternatif untuk meningkatkan ketahanan pangan, mengacu kepada tingginya potensi lahan pekarangan serta masih tersedianya potensi tenaga kerja keluarga yang belum termanfaatkan.

Inovasi teknologi pada dasarnya mempunyai peranan yang tinggi terhadap usaha pemanfaatan pekarangan. Penggunaan teknologi yang tepat akan berpeluang menekankan biaya produksi, meningkatkan harga jual, serta meningkatkan daya saing produk. Inovasi teknologi pemanfaatan pekarangan dapat diterima dan diterapkan dengan baik, jika pemilik lahan pekarangan (ibu rumah tangga) memiliki persepsi yang positif terhadap fungsi dan manfaat pekarangan dalam mendukung diversifikasi pangan keluarga. Persepsi dan pengetahuan yang benar dari ibu rumah tangga, akan memberikan apresiasi dan pertimbangan yang mengarah pula pada perilaku yang baik dalam pengelolaan pekarangan. Keputusan petani untuk mengadopsi teknologi pertanian baru, tergantung pada faktor-faktor yang kompleks, salah satu faktor adalah persepsi petani Bagheri et al., (2008).

Persepsi adalah proses yang diawali dengan penginderaan, yaitu proses yang berwujud diterimanya stimulus oleh individu melalui alat reseptornya yang diteruskan melalui pengolahan ingatan dan terjadi proses psikologis sehingga individu tersebut mengalami persepsi (pengertian).

Litterer (Asngari, 1984) menyatakan, mekanisme pembentukan persepsi seseorang terjadi melalui tiga tahap, yaitu: (1) selectivity, (2) closure, dan (3) interpretation. Menurut Asngari (1984) bahwa, ada keinginan atas kebutuhan manusia untuk mengetahui dan mengerti dunia tempat hidupnya, serta mengetahui makna dari informasi yang diterimanya. Tindakan seseorang sebagian dilandasi oleh persepsi mereka, termasuk keputusan untuk mengelola lahan pekarangan yang mereka miliki sebagai sumber keanekaragaman bahan pangan yang bergizi.

Rario et al., (2005) menyatakan bahwa, persepsi dan pengetahuan yang dimiliki petani, diperoleh dan dibentuk dari berbagai kondisi yang mendukung. Berdasarkan hal tersebut untuk dapat meningkatkan persepsi positif tentang fungsi dan manfaat pekarangan, maka perempuan perlu mendapat informasi, pembinaan dan bimbingan dari pemerintah maupun swasta melalui program penyuluhan dan juga pelatihan, sehingga dapat terjadi perubahan sikap mental maupun perilaku yang positif dalam pemanfaatan pekarangan yang ada di sekitar tempat tinggal.

Penelitian ini bertujuan untuk mendeskripsikan dan menganalisis persepsi perempuan terhadap fungsi dan manfaat pekarangan, diversifikasi pangan, makanan sehat dan faktor-faktor yang berhubungan dengan persepsi perempuan dalam pemanfaatan pekarangan mendukung diversifikasi pangan. 


\section{Metode Penelitian}

Penelitian menggunakan pendekatan kuantitatif, dilaksanakan Maret 2015 sampai Desember 2015. Lokasi penelitian di tiga kecamatan (Matuari, Ranowulu dan Girian) Kota Bitung dan 12 Kecamatan (Tondano Timur, Tondano Utara, Eris, Kakas Barat, Langowan Timur, Langowan Selatan, Langowan Utara, Tombulu, Kawangkoan, Kawangkoan Utara, Kawangkoan Barat, dan Tompaso) di Kabupaten Minahasa Sulawesi Utara. Kota Bitung dan Kabupaten Minahasa sebagai lokasi penelitian dipilih dengan pertimbangan bahwa kedua lokasi tersebut merupakan lokasi pelaksana program: Percepatan Penganekaragaman Konsumsi Pangan (P2KP) dan Model Kawasan Rumah Pangan Lestari (MKRPL).

Penelitian melibatkan 267 perempuan pemanfaat pekarangan yang telah mengikuti Program Percepatan Penganekaragaman Konsumsi Pangan (P2KP) dan Model Kawasan Rumah Pangan Lestari (MKRPL). Adapun populasi peserta program MKRPL dan P2KP sejumlah 803 orang. Besarnya jumlah sampel diperoleh dari perhitungan jumlah total rumah tangga (KK) kota dan kabupaten terpilih dengan menggunakan rumus Slovin. Responden dipilih secara acak dengan metode simple random sampling. Metode simple random sampling dilakukan pada tingkat desa/ kelurahan.

Data yang dikumpulkan terdiri dari data primer dan data sekunder. Data primer dikumpulkan melalui:
(1) observasi pada lahan pekarangan; (2) wawancara dengan menggunakan kuesioner yang disusun dalam bentuk pertanyaan tertutup dan terbuka; dan (3) wawancara mendalam. Kuesioner tertutup dibuat berdasarkan skala Likert dengan empat skala: rendah (Skala 1), sedang (Skala 2), tinggi (Skala 3), sangat tinggi (Skala 4).

Pengolahan dan analisis data menggunakan analisis deskriptif, analisis korelasi Rank Spearman dan uji beda Mann Whitney. Uji beda Mann Whitney digunakan untuk melihat apakah ada perbedaan persepsi perempuan di Kabupaten Minahasa dan Kota Bitung terhadap pemanfaatan pekarangan mendukung diversifikasi pangan. Persepsi yang diukur adalah: persepsi terhadap fungsi dan manfaat pekarangan, persepsi terhadap diversifikasi pangan dan persepsi terhadap makanan sehat. Peubah yang diukur (Gambar 1) adalah: Karakteristik perempuan $\left(X_{1}\right)$; Aksesibilitas terhadap informasi $\left(\mathrm{X}_{2}\right)$; Lingkungan $\left(\mathrm{X}_{3}\right)$; Peran kelompok $\left(\mathrm{X}_{4}\right)$; Penyuluhan $\left(\mathrm{X}_{5}\right)$; dan Persepsi $\left(\mathrm{Y}_{1}\right)$.

\section{Hasil dan Pembahasan}

\section{Tingkat Persepsi Perempuan terhadap Pemanfaatan Pekarangan}

Tingkat persepsi perempuan tentang fungsi dan manfaat pekarangan tergolong tinggi dengan skor skala Likert 3,25 (Tabel 1). Hasil ini menunjukkan bahwa, penilaian dan pemahaman perempuan terhadap fungsi dan manfaat pekarangan sebagai sumber

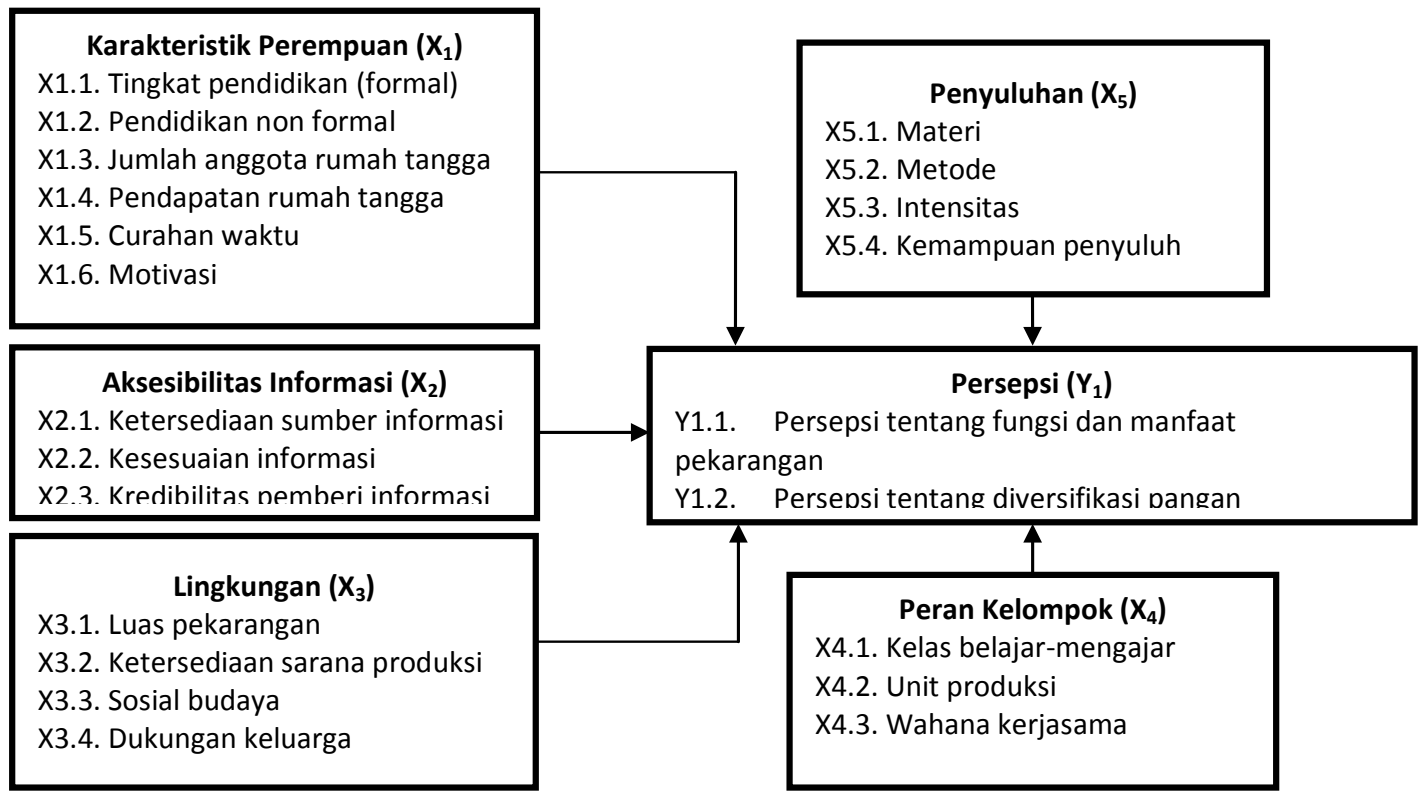

Gambar 1. Kerangka Berpikir Persepsi Perempuan terhadap Pemanfaatan Pekarangan Mendukung Diversifikasi Pangan 
keanekaragaman pangan bagi keluarga sudah baik. Tingginya persepsi tersebut karena, menurut mereka pekarangan sudah berfungsi sebagai penghasil bahan pangan bagi keluarga mereka. Pekarangan yang mereka tanami dengan aneka ragam tanaman khususnya tanaman pangan (sayuran dan buah-buahan) serta pemeliharaan ternak (ayam, babi, itik, bebek, anjing, serta ikan) dapat mereka gunakan sebagai tambahan untuk ketersediaan sumber karbohidrat, vitamin, mineral, serta protein bagi keluarga. Hasil dari usaha pemanfaatan pekarangan juga dapat diambil sewaktuwaktu jika mereka perlukan, sehingga tidak perlu ke pasar untuk mendapatkan komoditas yang diperlukan. Frekuensi pengambilan hasil pekarangan 2-3 kali dalam seminggu. Perempuan juga merasakan dengan dioptimalkannya pekarangan yang mereka miliki, dapat mencukupi kebutuhan pangan mikro dan gizi keluarga, bahkan dapat menghemat pengeluaran keuangan di bidang pangan, sehingga dapat menambah pendapatan keluarga. Hasil penelitian Adenkule (2013) menunjukkan, berkebun di rumah merupakan cara untuk meningkatkan ketahanan pangan, kesehatan dan interelasi sosial rumah tangga di masyarakat Afrika Selatan. Buchmann (2009) menyatakan, kebun rumah di Cuba merupakan hal penting dalam meningkatkan keamanan pangan dan mengurangi kerentanan pangan rumah tangga. Alieteri et al., (1999) juga menyatakan bahwa, jenis komoditas yang ditanam di pekarangan di Cuba adalah jenis komoditas yang dibutuhkan oleh keluarga, sesuai ketersediaan pasar dan kesesuaian tanah.

Diversifikasi pangan adalah upaya peningkatan konsumsi aneka ragam pangan dengan prinsip gizi seimbang. Tingkat persepsi perempuan terhadap diversifikasi pangan tergolong tinggi dengan skor skala Likert 3,02. Namun, hasil uji beda Mann Whitney menunjukkan bahwa terdapat perbedaan persepsi antara perempuan di Bitung dan Minahasa. Perempuan di kedua lokasi sependapat bahwa diversifikasi pangan penting untuk kesehatan, karena melalui konsumsi makanan yang beranekaragam kebutuhan akan gizi keluarga dapat tercukupi. Meskipun persepsi mereka terhadap diversifikasi pangan tergolong tinggi, pada kenyataannya diversifikasi pangan belum mampu mengurangi konsumsi beras, terutama di Minahasa. Hal ini didukung oleh budaya setempat yang beranggapan bahwa: "jika belum makan nasi, itu dianggap mereka belum makan." Diversifikasi pangan yang ada di lokasi penelitian masih lebih bersifat kuantitas (asal kenyang) belum bersifat kualitas (gizi berimbang). Perempuan di kedua lokasi belum menerapkan diversifikasi pangan pokok secara baik, karena mereka masih sulit dalam mengubah pola makan.

Makanan sehat diartikan sebagai makanan yang memiliki dan mengandung gizi yang seimbang, mengandung serat dan zat-zat yang diperlukan tubuh.

Tabel 1. Deskripsi Persepsi Perempuan Pemanfaat Pekarangan terhadap Pemanfaatan Pekarangan di Bitung dan Minahasa, 2015

\begin{tabular}{|c|c|c|c|c|c|c|c|}
\hline \multirow[t]{2}{*}{ No } & \multirow[t]{2}{*}{ Persepsi } & \multirow[t]{2}{*}{ Kategori } & \multicolumn{2}{|c|}{ Frekuensi $(n=267)$} & \multirow[t]{2}{*}{ Total } & \multirow[t]{2}{*}{$\begin{array}{c}\text { Skor } \\
\text { Persepsi } \\
\end{array}$} & \multirow[t]{2}{*}{ U- Test } \\
\hline & & & Minahasa & Bitung & & & \\
\hline \multirow{4}{*}{1} & Persepsi & Rendah $(1,00-1,49)$ & 0 & 0 & 0 & 3,25 & 0,664 \\
\hline & tentang & Sedang $(1,50-2,49)$ & 2 & 0 & 2 & & \\
\hline & fungsi dan & Tinggi $(2,50-3,49)$ & 99 & 96 & 195 & & \\
\hline & $\begin{array}{l}\text { manfaat } \\
\text { pekarangan }\end{array}$ & Sangat tinggi $(3,50-4,00)$ & 39 & 31 & 70 & & \\
\hline \multirow[t]{4}{*}{2} & Persepsi & Rendah $(1,00-1,49)$ & 0 & 0 & 0 & 3,02 & $0,023^{*}$ \\
\hline & tentang & Sedang $(1,50-2,49)$ & 5 & 5 & 10 & & \\
\hline & diversifikasi & Tinggi $(2,50-3,49)$ & 133 & 109 & 242 & & \\
\hline & pangan & Sangat tinggi $(3,50-4,00)$ & 2 & 13 & 15 & & \\
\hline \multirow[t]{4}{*}{3} & Persepsi & Rendah $(1,00-1,49)$ & 0 & 0 & 0 & 3,19 & 0,166 \\
\hline & tentang & Sedang $(1,50-2,49)$ & 1 & 2 & 3 & & \\
\hline & makanan & Tinggi $(2,50-3,49)$ & 107 & 104 & 211 & & \\
\hline & sehat & Sangat tinggi $(3,50-4,00)$ & 32 & 21 & 53 & & \\
\hline
\end{tabular}

Keterangan: * Signifikan korelasi pada level 0,05 
Tabel 1 menunjukkanbahwatingkatpersepsiperempuan tentang makanan sehat tergolong tinggi dengan skor persepsi sebesar skala Likert 3,19. Menurut pendapat perempuan, makanan yang mereka konsumsi dapat berpengaruh terhadap kesehatan mereka dan keluarga. Mereka sependapat bahwa makanan sehat ditentukan oleh komposisi gizi yang terkandung dalam makanan, dan makan makanan sehat seharusnya menjadi gaya hidup mereka. Makanan yang dikonsumsi sebaiknya diproduksi secara alami tanpa penggunaan bahanbahan kimia serta rekayasa genetik seperti buah dan sayuran organik yang semuanya itu dapat diproduksi atau dihasilkan dari pekarangan yang mereka miliki. Mereka setuju bahwa pangan sehat yang diperoleh dari pekarangan dapat diusahakan dengan cara budidaya tanaman secara organik tanpa menggunakan pupuk dan pestisida kimia buatan pabrik. Pemupukan dan pengendalian hama-penyakit dapat dibuat sendiri dengan menggunakan bahan-bahan organik yang tersedia di sekitar mereka. Marsh (1998) dan Galhena et al., (2013) menyatakan bahwa, beberapa manfaat yang paling penting dari berkebun di rumah adalah peningkatan akses langsung ke bermacam-macam makanan segar, bergizi dan sehat. Selanjutnya dikatakan pula lebih dari $50 \%$ dari sayuran, buahbuahan, umbi-umbian, dan ubi jalar yang dikonsumsi ditanam di pekarangan.

\section{Analisis Faktor-Faktor yang Berhubungan dengan Persepsi}

Tabel 2 menunjukkan, jumlah anggota keluarga berhubungan nyata positif $(a=0,05)$ dengan persepsi perempuan terhadap diversifikasi pangan. Jumlah anggota keluarga berhubungan dengan jumlah dan jenis makanan yang akan dikonsumsi. Sejalan dengan hasil penelitian Kobe (Meng et al., 2012) bahwa, pola konsumsi sayur berhubungan dengan jumlah anggota keluarga. Semakin banyak anggota keluarga dalam rumah tangga, menu makanan yang dikonsumsi semakin beragam dan secara kuantitas, konsumsi pangan semakin bertambah. Ini disebabkan karena selera makanan dari anggota keluarga berbeda satu dengan lainnya. Upaya untuk memenuhi keinginan anggota keluarga dilakukan dengan menganekaragamkan pangan yang akan dikonsumsi oleh keluarga. Pertambahan kebutuhan konsumsi pangan ini, membuat perempuan memutuskan untuk memilih jenis pangan tertentu yang lebih murah dan mudah didapatkan dalam jumlah yang lebih banyak, tetapi lebih ke arah memenuhi unsur kenyang, belum untuk memenuhi kebutuhan gizi anggota rumah tangga. Suryastiri (2008) menyatakan bahwa, semakin banyak jumlah anggota keluarga maka beban yang ditanggung rumah tangga akan semakin besar.

Tabel 2. Nilai Koefisien Korelasi antara Karakteristik Individu, Aksesibilitas terhadap Informasi dan Persepsi

\begin{tabular}{|c|c|c|c|c|c|c|c|}
\hline \multirow{3}{*}{ No } & \multirow{3}{*}{ Peubah } & \multicolumn{6}{|c|}{ Persepsi $(n=267)$} \\
\hline & & \multicolumn{2}{|c|}{$\begin{array}{l}\text { Fungsi dan Manfaat } \\
\text { Pekarangan }\end{array}$} & \multicolumn{2}{|c|}{$\begin{array}{l}\text { Diversifikasi } \\
\text { Pangan }\end{array}$} & \multicolumn{2}{|c|}{ Makanan Sehat } \\
\hline & & $\mathbf{r}_{\mathrm{s}}$ & $\mathbf{P}$ & $\mathbf{r}_{\mathrm{s}}$ & $\mathbf{P}$ & $\mathbf{r}_{\mathrm{s}}$ & $\mathbf{P}$ \\
\hline \multicolumn{8}{|c|}{ Karakteristik Individu } \\
\hline 1 & Tingkat pendidikan formal & 0,019 & 0,754 & 0,018 & 0,768 & 0,067 & 0,275 \\
\hline 2 & Pendidikan nonformal & 0,070 & 0,253 & 0,085 & 0,164 & 0,022 & 0,718 \\
\hline 3 & Jumlah anggota keluarga & 0,036 & 0,561 & $0,140^{*}$ & 0,023 & 0,054 & 0,378 \\
\hline 4 & Pendapatan keluarga & 0,038 & 0,541 & 0,111 & 0,070 & 0,059 & 0,337 \\
\hline 5 & Curahan waktu & $-0,033$ & 0,594 & 0,049 & 0,425 & $-0,129^{*}$ & 0,036 \\
\hline 6 & Motivasi & 0,065 & 0,290 & $-0,062$ & 0,316 & $-0,076$ & 0,215 \\
\hline \multicolumn{8}{|c|}{ Aksesibilitas terhadap Informasi } \\
\hline 1 & Ketersediaan informasi & $0,150^{*}$ & 0,014 & $-0,043$ & 0,485 & 0,079 & 0,196 \\
\hline 2 & $\begin{array}{l}\text { Kesesuaian informasi yang } \\
\text { diterima }\end{array}$ & $0,202^{* *}$ & 0,001 & $0,284^{* *}$ & 0,000 & $0,194^{* *}$ & 0,001 \\
\hline 3 & Kredibilitas pemberi informasi & $-0,041$ & 0,507 & $0,122^{*}$ & 0,046 & $-0,025$ & 0,685 \\
\hline
\end{tabular}

Keterangan: **. Signifikan korelasi pada level 0,01

*. Signifikan korelasi pada level 0,05 
Munparidi (Surahman et al., 2013) menyatakan bahwa, proporsi alokasi pengeluaran untuk konsumsi pangan berbanding terbalik dengan besarnya pendapatan total keluarga.

Curahan waktu berhubungan nyata negatif $(a=0,05)$ dengan persepsi perempuan tentang makanan sehat. Tingginya persepsi terhadap makanan sehat, belum didukung dengan curahan waktu yang dipergunakan pada kegiatan pemanfaatan pekarangan yang dapat menghasilkan makanan sehat. Ini disebabkan karena upaya perempuan untuk menyajikan makanan sehat bagi keluarga adalah dengan cara memasak sendiri, sedangkan ketersediaan bahan pangan di pekarangan jumlahnya masih terbatas. Pemerolehan bahan pangan cenderung masih berasal dari luar (membeli) bukan dari pekarangan, sehingga waktu yang dipergunakan oleh perempuan lebih tercurah pada kegiatan memasak dan membeli bahan pangan.

Perempuan pemanfaat pekarangan memerlukan beragam informasi untuk mendukung usaha pekarangannya. Informasi yang dibutuhkan oleh perempuan di Minahasa dan Bitung tidak hanya informasi tentang peningkatan produksi tanaman, tetapi juga informasi mengenai pascapanen (pengolahan, penyimpanan, dan penanganan) dan pemasaran, serta keberlanjutan usaha pekarangan (manajemen usaha pekarangan). Menurut van den Ban (1999), petani membutuhkan informasi tepat guna, manajemen teknologi, termasuk penggunaan input yang optimal, pilihan berusaha tani. Kemudahan akses terhadap informasi tersebut diharapkan dapat mendorong perempuan untuk terus mencari informasi dalam mendukung kegiatan usaha pekarangannya.

Tabel 2 menunjukkan bahwa ketersediaan informasi yang diterima oleh perempuan berhubungan nyata $(a=0,05)$ dengan persepsi mereka terhadap fungsi dan manfaat pekarangan. Nilai korelasi yang diperoleh antara ketersediaan informasi yang diterima dengan persepsi perempuan terhadap fungsi dan manfaat pekarangan tersebut mengindikasikan bahwa semakin banyak ketersediaan informasi teknologi tentang pemanfaatan pekarangan maka semakin tinggi pula persepsi perempuan terhadap fungsi dan manfaat pekarangan. Ketersediaan sumber informasi akan berpengaruh terhadap intensitas perempuan dalam mengakses informasi yang mereka butuhkan untuk mendukung kegiatan usaha pekarangannya. Sejalan dengan penelitian Bulu et al., (2008), bahwa ketersediaan informasi sesuai jenis, jumlah, kualitas, dan tepat waktu saat dibutuhkan petani mampu meningkatkan adopsi inovasi teknologi. Tersedianya berbagai informasi teknologi pertanian akan mempercepat kemajuan usaha pertanian.

Kesesuaian informasi yang diterima oleh perempuan pemanfaat pekarangan, berhubungan positif sangat nyata dengan semua persepsi perempuan. Nilai korelasi sangat nyata tersebut mengindikasikan bahwa tingkat kesesuaian informasi sangat menentukan persepsi dari perempuan pemanfaat pekarangan. Semakin sesuainya informasi pemanfaatan pekarangan danpengolahanpanganbersumberdaripekaranganyang diterima, akan meningkatkan persepsi positif terhadap pemanfaatan pekarangan mendukung diversifikasi pangan. Sebagian besar perempuan menyatakan bahwa informasi yang mereka terima mengenai pemanfaatan pekarangan, diversifikasi pangan dan informasi tentang makanan sehat, semuanya sesuai dengan yang mereka butuhkan. Menurut penilaian mereka, optimalisasi lahan pekarangan sebagai sumber bahan pangan bagi keluarga, dapat mereka lakukan dengan mudah, apabila diberikan informasi secara benar dan jelas.

Kredibilitas orang/pemberi informasi hanya berhubungan nyata positif $(a=0,05)$ dengan persepsi perempuan tentang diversifikasi pangan. Makna dari hubungan ini adalah semakin tingginya kredibilitas dari pemberi informasi dalam memberikan informasi mengenai diversifikasi pangan sampai pada alternatif pangan lokal, akan meningkatkan persepsi yang positif terhadap makna dari diversifikasi pangan. Hasil penelitian Azhari et al., (2013) menunjukkan bahwa, penyuluhan yang dilakukan dalam upaya peningkatan diversifikasi pangan rumah tangga berhasil mengubah persepsi masyarakat ke arah positif terhadap diversifikasi pangan. Hal ini berarti bahwa penyuluhan yang diarahkan secara khusus pada upaya peningkatan diversifikasi pangan melalui pemanfaatan pekarangan, dapat mengubah pengetahuan dan pemahaman masyarakat mengenai diversifikasi pangan, sehingga mereka bisa memandang positif dan mendukung upaya diversifikasi pangan rumah tangga.

Hasil analisis uji korelasi menunjukkan bahwa, ketersediaan sarana produksi (Tabel 3) berhubungan nyata positif $(a=0,01)$ dengan persepsi tentang fungsi dan manfaat pekarangan, persepsi tentang diversifikasi pangan serta persepsi tentang makanan sehat. Hubungan ini mengindikasikan bahwa, semakin tinggi ketersediaan sarana produksi yang mendukung kegiatan pemanfaatan pekarangan dan pengolahan pangan yang ada di lokasi penelitian, akan meningkatkan 
Tabel 3. Nilai Koefisien Korelasi antara Lingkungan, Peran Kelompok, Penyuluhan dengan Persepsi Perempuan tentang Pemanfaatan Pekaragan di Minahasa dan Bitung, 2015

\begin{tabular}{|c|c|c|c|c|c|c|c|}
\hline \multirow{3}{*}{ No } & \multirow{3}{*}{ Peubah } & \multicolumn{6}{|c|}{ Persepsi $(n=267)$} \\
\hline & & \multicolumn{2}{|c|}{$\begin{array}{c}\text { Fungsi dan } \\
\text { Manfaat } \\
\text { Pekarangan } \\
\end{array}$} & \multicolumn{2}{|c|}{ Diversifikasi Pangan } & \multicolumn{2}{|c|}{ Makanan Sehat } \\
\hline & & $\mathbf{r}_{\mathrm{s}}$ & $\mathbf{P}$ & $\mathbf{r}_{\mathrm{s}}$ & $\mathbf{P}$ & $\mathbf{r}_{\mathrm{s}}$ & $\mathbf{P}$ \\
\hline \multicolumn{8}{|c|}{ Lingkungan } \\
\hline 1 & Luas pekarangan & 0,004 & 0,949 & $-0,006$ & 0,928 & 0,018 & 0,766 \\
\hline 2 & Ketersediaan sarana produksi & $0,195^{* *}$ & 0,001 & $0,210^{* *}$ & 0,001 & $0,199^{* *}$ & 0,001 \\
\hline 3 & Sosial budaya & 0,068 & 0,269 & $-0,071$ & 0,247 & 0,004 & 0,946 \\
\hline 4 & Dukungan keluarga & $0,139^{*}$ & 0,023 & 0,094 & 0,125 & $-0,048$ & 0,438 \\
\hline \multicolumn{8}{|c|}{ Peran Kelompok } \\
\hline 1 & Kelas belajar mengajar & $0,332^{* *}$ & 0,000 & 0,077 & 0,208 & $0,308^{* *}$ & 0,000 \\
\hline 2 & Unit produksi & $0,279^{* *}$ & 0,000 & 0,033 & 0,593 & $0,190^{* *}$ & 0,002 \\
\hline 3 & Wahana kerjasama & $0,399^{* *}$ & 0,000 & 0,022 & 0,725 & $0,293^{* *}$ & 0,000 \\
\hline \multicolumn{8}{|c|}{ Penyuluhan } \\
\hline 1 & Materi & $0,295^{* *}$ & 0,000 & 0,060 & 0,328 & $0,343^{* *}$ & 0,000 \\
\hline 2 & Metode & $0,244^{* *}$ & 0,000 & 0,010 & 0,870 & $0,176^{* *}$ & 0,004 \\
\hline 3 & Intensitas & $0,341^{* *}$ & 0,000 & 0,009 & 0,885 & $0,243^{* *}$ & 0,000 \\
\hline 4 & Kemampuan penyuluh & $0,392^{* *}$ & 0,000 & 0,082 & 0,180 & $0,370^{* *}$ & 0,000 \\
\hline
\end{tabular}

Keterangan: **. Signifikan korelasi pada level 0,01

persepsi positif yang dimiliki oleh perempuan dalam memanfaatkan pekarangan sebagai sumber pangan dan gizi bagi keluarga. Ketersediaan sarana produksi yang berkaitan dengan pemanfaatan pekarangan sebagai sumber bahan pangan, guna mendukung diversifikasi pangan seperti: benih/bibit aneka jenis tanaman sayuran (hibrida maupun non hibrida), pupuk, polybag pestisida, media tanam, di lokasi penelitian (Kabupaten Minahasa dan Kota Bitung) dikategorikan tersedia. Yunita (2013) menyatakan bahwa, aspekaspek dalam lingkungan sosial yang paling berpotensi mempengaruhi pengembangan kapasitas rumah tangga petani dalam mencapai ketahanan pangan rumah tangga adalah akses terhadap sarana produksi. Hasil penelitian yang dilakukan oleh Ashari et al., (2012) menunjukkan bahwa, masalah yang didapati petani pada usaha pemanfaatan pekarangan adalah sarana produksi seperti bibit, air, dan pupuk organik.

Ketersediaan dan kemudahan mendapatkan sarana produksi pertanian menjadikan perempuan lebih baik dalam memanfaatkan pekarangan. Mereka lebih lancar dalam melakukan kegiatan usaha pemanfaatan pekarangan terutama dalam hal pemenuhan keperluan benih, pupuk dan sarana produksi lainnya. Hal ini sejalan dengan pendapat Mosher (1987) yang
*. Signifikan korelasi pada level 0,05

menyatakan bahwa, tersedianya sarana merupakan syarat pokok dalam pembangunan pertanian. Hasil penelitian Metalisa et al., (2014) menunjukkan bahwa, ketersediaan sarana produksi berpengaruh nyata terhadap tujuan pemanfaatan pekarangan. Perempuan yang memiliki sarana produksi yang berada di lingkungannya dan mudah untuk memperolehnya, menjadi salah satu faktor untuk mendorong tujuan pemanfaatan lahan pekarangan.

Dukungankeluarga diartikansebagaisikap serta tindakan nyata keluarga yang mendukung perempuan dalam melakukan kegiatan pemanfaatan pekarangan sebagai sumber bahan pangan keluarga. Hasil analisis data menunjukkan bahwa dukungan keluarga berhubungan nyata positif $(a=0,05)$ dengan persepsi perempuan tentang fungsi dan manfaat pekarangan.

Hal ini mengindikasikan bahwa semakin tinggi dukungan keluarga yang diberikan pada perempuan dalam kegiatan pemanfaatan pekarangan mendukung diversifikasi pangan, maka akan meningkatkan persepsi perempuan terhadap kegiatan pemanfaatan pekarangan. Dukungan keluarga dilakukan melalui kerjasama dalam perencanaan dan pelaksanaan usaha pemanfaatan pekarangan yang sesuai dengan kondisi pekarangan yang ada, sehingga pemanfaatan 
pekarangan dapat meningkatkan konsumsi energi dan konsumsi protein bagi rumah tangga secara nyata, mengurangi pengeluaran untuk konsumsi pangan serta produksi usaha pekarangan dapat berkesinambungan.

Pengetahuan tentang pemanfaatan pekarangan dan gizi seimbang yang dimiliki perempuan merupakan bagian dari proses pembelajaran yang dapat dilaksanakan di dalam kelompok. Kelompok sebagai kelas belajar, unit produksi dan wahana kerjasama, sangat berperan dalam peningkatan pengetahuan tentang pengelolaan pangan yang bersumber dari pekarangan, sehingga menghasilkan pangan yang bergizi bagi keluarga. Pendidikan atau pengetahuan pemanfaatan pekarangan dan gizi seimbang yang diberikan pada perempuan sebagai ibu rumahtangga, akan memberikan stimulus mengenai berbagai manfaat gizi yang terkandung dalam makanan dan pekarangan sebagai salah satu sumber pangan yang potensial bagi keluarga.

Stimulus yang diperoleh dari proses pembelajaran ini akan dapat memberikan perbedaan persepsi dan pemahaman terhadap informasi yang diberikan. Dengan meningkatnya pengetahuan yang dimiliki oleh perempuan, diharapkan akan mengubah persepsi mereka tentang pemanfaatan pekarangan. Ini berarti bahwa semakin tinggi peran kelompok, maka akan semakin tinggi pula persepsi perempuan terhadap fungsi dan manfaat pekarangan, serta persepsi tentang makanan sehat. Tabel 3 menunjukkan bahwa peran kelompok sebagai kelas belajar mengajar, peran kelompok sebagai unit produksi dan peran kelompok sebagai wahana kerjasama berkorelasi sangat nyata positif $(\mathrm{a}=0,01)$ dengan persepsi perempuan terhadap fungsi dan manfaat pekarangan, serta persepsi tentang makanan sehat. Hasil penelitian Patrick (2013) menunjukkan, persepsi dipengaruhi oleh keanggotaan dalam kelompok produsen kedelai. Hal ini juga sejalan dengan hasil penelitian Wahyuni et al., (2007) yang menunjukkan, pengaruh kelompok berhubungan nyata positif dengan usaha pembaca dalam memperoleh sumber informasi.

Penyuluhanadalah proses pendidikannonformal dalam penyampaian pesan-pesan/inovasi pemanfaatan pekarangan, dengan tujuan agar terjadi perubahan perilaku pada perempuan pemanfaat pekarangan (peningkatan kompetensi terhadap pemanfaatan pekarangan mendukung diversifikasi pangan). Tabel 3 menunjukkan semua peubah penyuluhan (materi penyuluhan, metode penyuluhan, intensitas penyuluhan, serta kemampuan penyuluh), berhubungan nyata positif $(a=0,01)$ dengan persepsi perempuan tentang fungsi dan manfaat pekarangan serta persepsi tentang makanan sehat. Hasil penelitian Patrick (2013) menunjukkan bahwa, persepsi dipengaruhi oleh frekuensi kontak dengan organisasi yang mempromosikan penggunaan inokulan Biofix. Azhari et al., (2013) menyatakan, semakin baik peran penyuluh sebagai komunikator, akan menyebabkan persepsi masyarakat terhadap diversifikasi pangan semakin meningkat, dan semakin baik peran penyuluh sebagai motivator maka persepsi masyarakat terhadap diversifikasi pangan juga akan semakin meningkat. Implikasi dari hasil analisis korelasi ini adalah, penyuluhan merupakan kunci utama yang harus diperkuat dan ditingkatkan agar persepsi perempuan terhadap pemanfaatan pekarangan mendukung diversifikasi pangan semakin meningkat.

\section{Kesimpulan}

Perempuan pemanfaat pekarangan di Minahasa dan Bitung sudah mempunyai persepsi yang baik/tinggi terhadap fungsi dan manfaat pekarangan, diversifikasi pangan dan pentingnya makanan sehat. Untuk itu, penyuluh sebagai petugas pendamping, perlu terus memotivasi dan mendampingi perempuan serta kelompok wanita tani untuk dapat terus melakukan usahatani di lahan pekarangan, dengan memperkenalkan teknologi yang sesuai dengan kondisi spesifik lokasi, dengan mempertimbangkan ketersediaan sumberdaya yang ada. Selain itu pemerintah setempat masih perlu membantu dengan memfasillitasi modal yang dibutuhkan perempuan untuk mengembangkan usaha pekarangannya.

Persepsi tentang fungsi dan manfaat pekarangan berhubungan nyata dengan ketersediaan dan kesesuaian informasi, ketersediaan sarana produksi, dukungan keluarga, peran kelompok dan penyuluhan. Persepsi tentang diversifikasi pangan berhubungan nyata dengan jumlah anggota keluarga, kesesuaian informasi, kredibilitas pemberi informasi, dan ketersediaan sarana produksi. Persepsi tentang makanan sehat berhubungan nyata dengan kesesuaian informasi, ketersediaan sarana produksi, peran kelompok, dan penyuluhan.

Persepsi perempuan terhadap fungsi dan manfaat pekarangan, serta makanan sehat dipengaruhi oleh peran kelompok dan penyuluhan. Untuk itu perlu pengaktifan kelompok wanita tani serta peningkatan kuantitas dan kualitas pelatihan/penyuluhan, sehingga dapat mengubah pola pikir perempuan dan keluarganya dalam upaya pemanfaatan pekarangan, bukan saja 
sekedar mengisi lahan yang kosong, tetapi lebih selektif dalam memilih komoditas yang mempunyai nilai guna dan nilai ekonomi. Selain itu, perlu adanya kesadaran dari para petugas pendamping dalam melaksanakan tugasnya untuk mendampingi pelaksanaan kegiatan yang dilakukan oleh anggota kelompok.

\section{Daftar Pustaka}

Adenkule OO. 2013. The Role of Home Gardens in Household Food Security in Eastern Cape: A Case Study of Three Villages in Nkonkobe Municipality. Journal of Agricultural Science, 5 (10): 67-76.

Ariningsih E, Handewi PR. 2008. Strategi Peningkatan Ketahanan Pangan Rumah Tangga Rawan Pangan, Jurnal Analisis Kebijakan Pertanian, 6 (3): 239255.

Ashari, Saptana, Purwantini TB. 2012. Potensi dan Prospek Pemanfaatan Lahan Pekarangan untuk Mendukung Ketahanan Pangan. Forum Penelitian Agro Ekonomi, 30 (1): 13 - 30.

Asngari PS. 1984. Persepsi Direktur Penyuluhan Tingkat Keresidenan dan Kepala Penyuluh Pertanian terhadap Peranan dan Fungsi Lembaga Penyuluhan Pertanian di Negara Bagian Texas Amerika Serikat. Media Peternakan, 9 (2).

Alieteri MA, Nelso C, Kristina C, Catherine M, Peter R, Martin B, Clara. 1999. The Greening of The "barrios": Urban Agriculture for Food Security in Cuba. Journal Agriculture and Human Values, 16: 131-140.

Azhari R, Muljono P, Tjitropranoto P. 2013. Peran Penyuluh dalam Peningkatan Diversifikasi Pangan Rumah Tangga. Jurnal Agro Ekonomi, 31 (2): 181-198.

Bagheri A, Fami HS, Rezvanfar A, Asadi A, Yazdani S. 2008. Perceptions of Paddy Farmers towards Sustainable Agricultural Technologies: Case of Haraz Catchments Area in Mazandaran Province of Iran. American Journal of Applied Sciences, 5 (10): 1384-1391.

Buchmann C. 2009. Cuban Home Gardens and Their Role in Social-Ecological Resilience. Journal Human Ecology, 37: 705-721.

Bulu YG, Hariadi SS, Ageng S, Herianto, Mudiyono. 2008. Pengaruh Modal Sosial dan Keterdedahan Informasi Inovasi terhadap Tingkat Adopsi Inovasi Jagung di Kabupaten Lombok Timur Nusa Tenggara Barat. [internet]. [dapat diunduh di: http://www.pse.litbang.pertanian.go.id/].
Galhena DH, Russell F, Karim MM. 2013. Home gardens: A Promising Approach to Enhance Household Food Security and Wellbeing. Journal Agriculture and Food Security, 2-8.

Marsh R. 1998. Building on Traditional Gardening to Improve Household Food Security. Food Nutr Agr. 22: 4-14.

Maturbongs LH. 2008. Penguatan Sistem Pangan untuk Mewujudkan Ketahanan Pangan Wilayah dan Rumah Tangga Sebagai Basis Ketahanan Pangan Nasional. Jurnal Agroforestri, 3 (1): 20-27.

Meng T, Florkowski WJ, Shashi K, Ibrahim M. 2012. Food Expenditures and Income in Rural Households in the Northern Region of Ghana. Journal Agricultural \& Applied Economics, 30(1): 141-50.

Metalisa R, Amiruddin S, Prabowo T. 2014. Peran Ketua Kelompok Wanita Tani dalam Pemanfaatan Lahan Pekarangan yang Berkelanjutan. Jurnal Penyuluhan, 10 (2): 158-170.

Mosher AT. 1987. Menggerakkan dan Membangun Pertanian. Terjemahan dari: Getting Agriculture Moving. Jakarta: CV. Yasaguna.

Patrick SM. 2013. Farmer Perception, Use and Profitability Biofix on Soybean (Glycine Max) Production in Western Kenya. Department of Land Resource Management and Agricultural Technology Faculty of Agriculture University of Nairobi. [internet]. [dapat diunduh di https://www. n2africa.org/sites/].

Rario B, Kasto, Ritohardoyo S. 2005. Persepsi dan Perilaku Petani dalam Penanganan Risiko Pestisida pada Lingkungan di Kelurahan Kalampangan, Kecamatan Sabangau Kota Palangka Raya. Jurnal Manusia dan Lingkungan, 12 (1): 23-42.

Surachman, Novira K, Adi S. 2013. Social Economic Factors Effecting The Diversity of Dietary Consumtion in The Self Sufficient Dietary Village of Kubu Raya District. Jurnal Social Economic of Agriculture, 2 (2): 1-20.

Suryastiri YP. 2008. Diversifikasi Konsumsi Pangan Pokok Berbasis Potensi Lokal dalam Mewujudkan Ketahanan Pangan Rumahtangga Pedesaan di Kecamatan Semin Kabupaten Gunungkidul. Jurnal Ekonomi Pembangunan, 13 (1): 51-60.

Van den Ban, Hawkins HS. 1999. "Penyuluhan Pertanian." inAgricultural Extension. Translate Edition. Herdiasti AD, Ed. Yogyakarta (ID): Kanisius. 199.

Wahyuni ES, Sarma M, Pulungan I. 2007. FaktorFaktor yang Berhubungan dengan Perilaku 
Jurnal Penyuluhan, Maret 2017 Vol. 13 No. 1

Pembaca dalam Memperoleh Informasi Gaya Hidup Sehat (Studi Kasus Pembaca Tabloid Senior di Kecamatan Bogor Utara). Jurnal Penyuluhan, 3 (2): 101-109.

Yunita. 2013. Strategi Peningkatan Kapasitas Petani Padi Sawah Lebak Menuju Ketahanan Pangan Rumah Tangga di Kabupaten Ogan Ilir dan Ogan Komering Ilir Provinsi Sumatera Selatan. [Disertasi]. Bogor (ID): Institut Pertanian Bogor. 